\title{
NICHOLAS RAY: A BIOGRAPHICAL OUTLINE Bernard Eisenschitz
}

Raymond Nicholas Kienzle Jr. was born on August 7, 1911, in Galesville, Wisconsin, population 1500 . His father, Raymond Nicholas Kienzle, a contractor and a builder and the son of German immigrants, had divorced his first wife and married Lena Toppen, of Norwegian stock, eleven years his junior. Raymond Nicholas Kienzle Jr. was his father's last born and only boy after daughters Alice, Ruth, and Helen. The family grew up in a town surrounded by farmlands cultivated by European immigrants and still inhabited by Indians.

After World War I, Raymond Sr. decided to retire and to move back to the bigger city of La Crosse, twenty miles down the Mississippi. There Raymond Nicholas Jr. spent the years of prohibition and witnessed his father's early death in November 1926. While attending high school, he wrote and produced for local radio, and won a tristate radio competition, which he later recalled as "a scholarship to any university in the world."

In the summer of 1931, Nick Ray, as he had by then decided to call himself, left home for the University of Chicago. His academic career was short. Soon he moved to New York, where he met Jean Evans, a young writer just arrived from California. They lived together and eventually married. Meanwhile, Ray was invited by architect Frank Lloyd Wright to join Wright's newly created Taliesin Fellowship, less an educational center than a microcosm of Wright's utopian society. Nick Ray spent a few months with Wright, participating in the Playhouse's activities. After a sudden falling out with the architect, Ray went to Mexico, then returned to New York and Jean Evans. 
Back in New York, in 1934, he joined a left-wing theatre group, the Workers Lab, soon to be renamed Theatre of Action. Influenced by European forerunners, the troupe presented pieces and skits in the agit-prop style, moving scenery by subway, putting up shows before picket lines, at factories or in union halls. Several of the troupe's members became lifelong friends. Its musical director was Earl Robinson (better known as the composer of "Ballad for Americans" and the "Ballad of Joe Hill"). The troupe practiced communal living and strong discipline and training: every morning, before the afternoon and evening performances, classes were given by acknowledged professionals--performers, choreographers, and members of the Group Theatre.

During its first five years, the Theatre of Action performed before an estimated audience of 100,000 . By then the group felt the need to graduate to "legitimate" productions. They commissioned a play, The Young Go First, whose treatment of a timely subject, the CCC camps, sharply criticized Roosevelt's "militaristic" policy. The play was jointly directed by the Theatre of Action's founder, Alfred Saxe, and Elia Kazan, fresh from the Group on his first professional production. The Young Go First premiered at the Park Theatre in May 1935, with a cast including "Nik" Ray as the camp barber. A year later, Ray appeared in the cast of the Theatre of Action's next and last production before the troupe disbanded, The Crime, a play of contemporary unionism directed by Saxe and Kazan (March 1936).

Ray would never forget the enthusiasm of his days with the Theatre of Action, nor Kazan's work with actors and the large amount of attention devoted to improvisation. Throughout his life, he kept in touch and worked with Will Lee, Perry Bruskin, Earl Robinson, Curt Conway, as well as with Kazan, Norman Lloyd, John Garfield, and Clifford Odets (who was to help him on a couple of screenplays). When he returned to the United States in the radical days of the late sixties and early seventies, he conceived the idea for a book (Stage Left!') about the theatrical "movement" of the thirties.

The Federal Theatre Project of the Works Progress Administration had been created in 1935. As the financial situation of the Theatre of Action had become impossible, several of its members individually joined the FTP in order to become equity members and to receive a basic salary. Ray, as stage manager and sometimes as actor, worked on one of the first "Living Newspaper" productions, Injunction Granted (with Norman Lloyd and "a cast of hundreds"; premiere: July 1936), directed by Joseph Losey, also from La Crosse. After the play's three-month run, Ray accepted an offer to take over theatrical 
activities at Brookwood Labor College, a Socialist-oriented workers' university run by unions. Bringing with him Earl Robinson as music director, he trained union activists in drama and acting.

Early in 1937, Ray was hired by the Resettlement Administration, headed by Rexford Tugwell, Secretary of Agriculture, and moved to Washington, D.C. Tugwell initiated a renaissance of grass-roots American culture. Nick Ray was put in charge of theatre art. His job was to get people to sit down and talk about their lives, to help them develop their awareness, create documentary plays, and express their problems and needs in theatrical terms. Ray also organized improvisation groups and worked with community theatres. By himself, sometimes with Jean Evans (who was pregnant), and once with Kazan, Ray went to mining camps, lumber camps, and the backwoods of the South. He brought one group from the mountains of Alabama to perform on the White House lawn for the Roosevelts and their guests. He enjoyed the company of the group in charge of the Archive of American Folk Song at the Library of Congress, Charles Seeger, his son, Peter, and Alan Lomax. The Rays (their son Anthony was born in November 1937) shared a house with the Lomaxes in a Washington suburb and lived and worked with folk singers like Josh White, Aunt Molly Jackson, Leadbelly, and Woody Guthrie. The WPA programs fell under severe political harassment, and Ray was discharged in July 1940, about the time he separated from Jean Evans.

Back in New York, Ray mixed with Café Society and the jazz scene. Together with Alan Lomax, he produced a weekly folk music program for CBS Radio: Back Where I Come From (August 1940-February 1941), featuring Burl Ives, Earl Robinson, Woody Guthrie, Pete Seeger, Leadbelly, Josh White, and the Golden Gate Quartet. He brought Leadbelly and Josh White to Max Gordon's Village Vanguard (November 1941).

After Pearl Harbor, Ray was rejected by the Army because of a congenital rheumatic heart condition. He was hired by John Houseman for the OWI (Office of War Information) Voice of America radio programs. Houseman put him in charge of folk music, and Ray reunited "Nick's Barefoot Boys," as the group of performers from Back Where I Come From was called. He also directed and supervised propaganda records and news programs in many languages and enjoyed working with the famous Czech comedians and political satirists Voskovec and Werich. The venture was soon brought to a close under pressure from anti-Roosevelt forces and a congressional investigation of OWI. Houseman resigned and was followed by the rest of his team.

Ray went to Hollywood in 1944, having been sent for by Elia Kazan, 
who was directing A Tree Grows in Brooklyn for 20th Century-Fox. Ray followed the whole production, without working in any specific capacity. Then he worked as a dialogue director for Fox and tried unsuccessfully to sell film ideas and break into the industry. Together with Joseph Losey, he staged a civic tribute to Franklin D. Roosevelt at the Academy Awards ceremony of 1945.

Ray was Houseman's general assistant on a short film for the Overseas Branch of the OWI, Tuesday in November (1945), designed to explain the American process of democratic elections to the world. The film combined documentary footage, staged scenes (directed by John Berry) and animated sequences (by John Hubley), and had a fulllength score by Virgil Thomson. Ray was responsible for post-production, including picture and sound editing. Back in New York in the summer of 1945, Houseman produced and Ray directed a pioneering TV drama, a half-hour program adapted from Lucille Fletcher's radio play, Sorry, Wrong Number, starring Mildred Natwick (in the role later played by Barbara Stanwyck in the film adaptation). Houseman next directed, assisted by Ray, a Broadway musical starring Mary Martin and Yul Brynner, Lute Song, premiered in February 1946. That same year, he and Houseman embarked on another musical inspired by The Beggar's Opera. It was to be the first integrated Broadway show, with a score by Duke Ellington and a libretto by John Latouche. Beggar's Holiday turned out to be expensive and disastrous: Houseman (as well as the star, Libby Holman) was fired and replaced, and Ray was the only director credited (for "staging the book") when the show reached New York (premiered in December 1946).

In 1946, Houseman had Nick hired as his assistant at RKO, and put him to work on a Depression-era novel, Thieves Like Us, by Edward Anderson. Ray wrote several drafts of a screenplay, hoping to direct it. In February 1947, when Dore Schary was appointed head of production at the studio and initiated a "new directors" policy, the studio agreed to let Ray direct the film. Thieves Like Us, retitled Your Red Wagon, then They Live By Night for release, was shot in 47 days during the summer of 1947. Its scheduled release was postponed when Howard Hughes bought the controlling shares of the studio (May 1948). Although Hughes had guaranteed Dore Schary unlimited freedom, the tycoon canceled three productions and put several completed films on the shelf: Schary promptly resigned. They Live By Night had only a minute release in October 1949.

In the meantime, Ray had directed a second feature for RKO, $A$ Woman's Secret, written and produced by his friend Herman J. Mankiewicz. It was during this film that he met Gloria Grahame, whom 
he married in June 1948, in Las Vegas. Their son, Tim, was born at the end of the year. On loan from the studio, Ray worked on Humphrey Bogart's first production. Knock on Any Door (1948, released 1949), adapted from a novel by black writer Willard Motley, was notable for its cast of young unknown actors. Next year, in 1949, Ray again directed Bogart, and Gloria Grahame, in a more personal film, In a Lonely Place (released in 1950), a film noir about the making and desintegration of a couple, reflecting Ray's own relationship with Grahame.

For the next few years, Nicholas Ray served under a long-term contract at Howard Hughes' RKO. In all, he directed six features (a third of his Hollywood output) for this studio: They Live By Night, A Woman's Secret (released in 1949), Born To Be Bad (1950), On Dangerous Ground (1952), Flying Leathernecks (1951), and The Lusty Men (1952): an even balance between personal, independent, and intense works and anonymous studio productions. As a Howard Hughes protégé, Ray was spared the agonies of blacklisting during the witchhunt, despite his leftist associations. He was able to wriggle his way out of directing I Married a Communist, without damage to his career. But he had to accomplish several chores for the studio or the eccentric billionaire, such as the "doctoring" (reshooting and supervising of editing and postproduction) of four films: Roseanna McCoy (1949, on loan to Samuel Goldwyn), The Racket (1951), Macao (1952, originally directed by Josef von Sternberg), and Androcles and the Lion (adding the notorious "Vestal Virgin Bath" sequence, which was much publicized but never made it to the screen; released in 1953). When Hughes sold his shares in RKO, Ray used a clause in his renewed contract to leave the studio, where he had spent seven years of his professional life (February 1953).

His ambition was to achieve independence by becoming his own producer. "Brilliant but unreliable," as he was considered by the industry, he was never to achieve this aim. Under the guidance of his agent, MCA, and the personal protection of the powerful Lew Wasserman, he was able to work uninterruptedly, going from one studio to another, but never as his own master. On his first film after RKO, Johnny Guitar (1953, released in 1954), he did serve as a producer, but the credit was denied him. After this tempestuous production, marked by clashes with the star, Joan Crawford, and day-to-day rewriting (all of which made for its greatness in the end), Ray directed James Cagney in another western, Run for Cover (1954, released in 1955). A short and brilliant TV episode, High Green Wall (1954, with Joseph Cotten) followed. By the end of 1954, he was at Warner Bros. 
xlvi

working on a project about youth, for which he had written the original story idea. Through different script drafts by Leon Uris, Irving Shulman, Stewart Stern, with notable contributions by Ray himself and producer David Weisbart, as well as extensive rehearsals and improvisational work with the young cast headed by James Dean, Rebel Without a Cause, produced in April-May 1955, became Ray's definitive, and certainly most celebrated, statement on youth when it was released in September, only a few days after Dean's tragic car crash.

Immediately after Rebel, Ray started Tambourine (released as Hot Blood in 1956), an old project of his, whose realization was marred by Jane Russell's and his own fatigue, but which François Truffaut hailed as "Nicholas Ray's joie de vivre" (as opposed to the French title of Rebel Without a Cause, La Fureur de vivre). On completion of the shooting, Ray went to Europe, both to promote Rebel and to try and set up independent production deals. On the news of Dean's death, he remained in Germany, and did not work on Hot Blood's post-production. He returned to the states for a two-film deal with 20th Century-Fox: Bigger Than Life and The True Story of Jesse James were both produced in 1956. At the beginning of 1957 he directed Bitter Victory, a European Columbia production, in Libya and in French studios, under arduous circumstances. Although Eric Rohmer described it as "the only intelligent film shown at the Venice Mostra," no other film project materialized in Europe at the time. Instead, Ray joined an American production by Budd and Stuart Schulberg, Wind Across the Everglades, shot in Florida from November 1957 to January 1958. An ill-prepared and ill-managed shooting, it suffered from the weather, writer Budd Schulberg's intent to be sole master on board and, last but not least, Ray's heavy drinking, eccentricities, and illness. He was barred from the last stages of shooting and from the editing, and was only able to see the film at a preview in July 1958. In the meantime, he had taken on an assignment at MGM, Party Girl (1958), which was to be his last Hollywood film.

In October 1958, Nick Ray married Betty Utey, a dancer and choreographer born in 1935. They had two daughters, Julie (born in January 1960) and Nikka (born in October 1961).

Ray next went to Britain and Italy to direct his own script of The Savage Innocents (released in 1960), an international coproduction backed by Paramount. He settled in Europe, intending to open an international film school, among other plans and projects. Those plans were postponed when he accepted an offer from Samuel Bronston, a producer of epics who was using Du Pont money and frozen 
assets to try setting up a new Hollywood in Spain. Ray brought to the Bronston "organization" two partners who subsequently became his producers: Philip Yordan (writer of Johnny Guitar) and Mikhail Wazsynski (a veteran director and jack-of-all-trades in EuropeanAmerican ventures). The first film he directed in Spain, King of Kings (released in 1961), was taken over by MGM and edited by the studio without his control. On the filming of his second Bronston picture, 55 Days at Peking (released in 1963), he suffered a heart attack and was replaced. Nicholas Ray's career within the legitimate film industry had come to an end in September 1962, on a set near Madrid.

Years of wandering across Europe followed. Ray opened a restaurant-night club in Madrid, served as a jury member at festivals, anonymously "doctored" scripts and films, and generally "kept his suitcases packed," living in turn in Rome, Madrid, London, Zagreb, Munich, Paris, and on the island of Sylt off Northern Germany. His most advanced project, based on Dylan Thomas's screenplay The Doctor and the Devils, fell through a few days before shooting was to begin in Yugoslavia (autumn 1965). A production with the Rolling Stones, like many others, never came to life.

Ray was finally brought back to the States by a group of young filmmakers who wanted him to direct a project about American justice. Seeing an opportunity to sum up his feelings about the revolt of youth (a wave of which he had witnessed in Paris, in May 1968), he first shot one of the largest of the anti-war rallies in Washington (March on Washington, Nov. 15, 1969, a short, was edited from the material), then flew to Chicago to follow the Chicago 7 trial. His involvement with the defendants and their lawyers led him to film the apartment of Fred Hampton immediately after the young Black Panther Party leader had been murdered by the Chicago police. Various sponsors supported the project, then backed off, as Ray kept shooting, by any means available, and began to edit his material. Director Marcel Ophuls recorded one stage of his effort in the documentary America Revisited (aired 1970). Under the strain, Ray suffered the loss of his sight in one eye.

A year later, Ray was hired as a film teacher by Harpur College at Binghamton, New York (September 1971). Believing "the only way to learn about film is to make films," he immediately started to shoot with his students. The "work in progress," called We Can't Go Home Again, made use of all possible formats and processes, including Nam June Paik's video synthesizer, to produce a new form of split screen. A first, hastily assembled version was shown at the end of the 1973 Cannes Film Festival. Ray remained in Europe for several months, 
still trying to complete the film. In Holland, he directed and acted in an episode of Wet Dreams, a soft-core feature designed to put the erotic dreams of various artists on screen.

Ray moved from Amsterdam to New York to San Francisco to Houston and back to New York, working away on We Can't Go Home Again, of which a shorter version, with his own narration, was prepared in April 1976. A documentary about him, A Stranger Here Myself, was premiered in 1975. Conceived by critic Myron Meisel and directed by David C. Helpern Jr. and James C. Gutman, the film was a sympathetic attempt to hide his physical deterioration. Finally, in 1976, Ray joined the Alcoholics Anonymous fellowship.

In November 1976, Nick moved into a SoHo loft with Susan Schwartz, whom he had met in Chicago in 1969 and who had been living and working with him since. A few months later, he acted in Wim Wenders's The American Friend (1977). He taught courses in film direction and film acting at the Lee Strasberg Institute and at New York University. Several video recordings and a short $16 \mathrm{~mm}$. film, Marco, were made in those classes. In fall 1977, Ray discovered he had cancer. He continued to teach between lengthy and painful medical treatments.

Early in 1978, his illness already apparent, Ray took a small part in Milos Forman's Hair (released in 1979). In March 1979, Nick Ray and Wim Wenders started shooting a joint project with the tentative title of Nick's Movie, eventually known as Lightning Over Water (released in 1980), from a line Ray improvised. The production came to a stop early in May. Ray died on June 16, 1979. 